\title{
Dietary Genistein Rescues Reduced Basal Chloride Secretion in Diabetic Jejunum via Sex-Dependent Mechanisms
}

\author{
Shawn Catmull Faisal Masood Sydney Schacht Robert Dolan Daniel Stegman \\ Lana Leung Layla Al-Nakkash
}

Department of Physiology, Arizona College of Osteopathic Medicine, Midwestern University, Glendale, USA

\section{Key Words}

$\mathrm{Ob} / \mathrm{Ob} \cdot$ Genistein $\cdot$ Intestinal $\cdot$ Secretion $\bullet$ Transport

\begin{abstract}
Background/Aims: The goal of this study was to determine the effect of dietary genistein (naturally occurring phytoestrogen) on jejunal secretory function in a clinically relevant model of diabetes and obesity, the leptin-deficient $o b / o b$ mouse. Methods: We measured transepithelial short circuit current $\left(\mathrm{I}_{\mathrm{sc}}\right)$, across freshly isolated segments of jejunum from 12 -week old male and female $o b / o b$ and lean C57BI/6J mice fed a genistein diet $(600 \mathrm{mg}$ genistein/kg diet) for 4-weeks. Separate segments of jejunum were frozen for western blot determination of key proteins involved in secretory transport. Results: Basal I $\mathrm{sc}_{\mathrm{sc}}$ was significantly decreased (by $33 \%, P<0.05$ ) in ob/ob females versus leans, and genistein-diet reversed this. Similarly, in males, basal $I_{s c}$ was decreased (by $47 \%, P<0.05$ ) in ob/ob mice versus leans, and genistein-diet reversed this. Inhibition with either clotrimazole $(100 \mu \mathrm{M}$, bilateral) or ouabain (100 $\mu \mathrm{M}$, basolateral) was significantly reduced in ob/ob mice compared to leans $(P<0.05)$, and genistein-diet reversed clotrimazole-sensitive inhibition in $o b / o b$ females, and reversed the ouabain-sensitive inhibition in males (indicating sex-dependent mechanisms). Our data suggested that PDE3 levels were dysregulated in $o b / o b$ females and genistein reversed this. Expression of total CFTR (normalized to actin) was significantly decreased $\sim 80 \%(P<0.05)$ in all $o b / o b$ mice compared to leans, and genistein-diet was without effect. Expression of total NKCC1 (normalized to actin) was significantly decreased $~ 80 \%(P<0.05)$ in ob/ob male mice versus leans, and genistein-diet reversed this. Conclusions: Our data suggests that the reduced basal jejunal $\mathrm{I}_{\mathrm{sc}}$ in $o b / o b$ female mice is a consequence of reduced CFTR expression, decreased activities of the basolateral $\mathrm{K}_{\mathrm{Ca}}$ channel and $\mathrm{Na}^{+} / \mathrm{K}^{+}$-ATPase, and in male mice reduced basal jejunal $\mathrm{I}_{s c}$ is a consequence of reduced CFTR and NKCC1 expression, along with decreased activities of the basolateral $\mathrm{K}_{\mathrm{Ca}}$ channel and $\mathrm{Na}^{+} / \mathrm{K}^{+}$-ATPase. Genistein-diet has beneficial effects on basal $\mathrm{I}_{\mathrm{sc}}$ mediated by sex-dependent mechanisms in diabetic mice: in females via increased $\mathrm{K}_{\mathrm{Ca}}$-sensitive $\mathrm{I}_{\mathrm{sc}}$ and in males via increased $\mathrm{Na}^{+} / \mathrm{K}^{+}$-ATPase activity and increased NKCC1 expression. Improved understanding of intestinal dysfunctions in the $o b / o b$ jejunum, may allow for the development of novel drug targets to treat obesity and diabetes, and may also be of benefit in CF-related diabetes.

(c) 2016 The Author(s)

Published by S. Karger AG, Basel

Professor Dr. Layla Al-Nakkash

Department of Physiology, Midwestern University, 19555 N. 59 th Avenue, Glendale, AZ 85308, (USA)

Tel. +1 623572-3719, Fax +1 623572-3673, E-Mail lalnak@midwestern.edu
\end{abstract}




\section{Cellular Physiology Cell Physiol Biochem 2016;40:335-346 \\ \begin{tabular}{l|l|l} 
and Biochemistry & $\begin{array}{l}\text { DOI: 10.1159/000452549 } \\
\text { Published online: November 21, } 2016\end{array}$ & $\begin{array}{l}\text { (c) } 2016 \text { The Author(s). Published by S. Karger AG, Basel } \\
\text { www.karger.com/cpb }\end{array}$ \\
\hline
\end{tabular} \\ Catmull et al.: Basal $\mathrm{Cl}^{-}$Secretion Increased by Genistein in $\mathrm{Ob} / \mathrm{Ob}$ Murine Jejunum}

\section{Introduction}

The leptin deficient $(o b / o b)$ mouse is a commonly utilized animal model for studies aimed at understanding type 2 diabetes and obesity [1]. The phenotype exhibited by this murine model closely mimics the gastrointestinal dysfunction seen clinically, including both slower gastrointestinal transit and gastric emptying time [2]. In addition to alterations in leptin function inherent to the $o b / o b$ mouse, disturbances in intestinal monosaccharide transport appears to also play a role in developing obesity and the diabetic state, purportedly via increased fructose absorption [3] mediated via GLUT transporters [4].

The small intestinal crypts are the site of $\mathrm{Cl}^{-}$secretion; $\mathrm{Cl}^{-}$enters the epithelial cells via the $\mathrm{Na}^{+} / \mathrm{K}^{+} / 2 \mathrm{Cl}^{-}$(NKCC1) co-transporter, and there is activation of both apical $\mathrm{Cl}^{-}$channels and basolateral $\mathrm{K}^{+}$channels. A driving force for $\mathrm{Cl}^{-}$exit across the apical membrane is maintained by recycling of $\mathrm{K}^{+}$across the basolateral membrane. In addition, the $\mathrm{Na}^{+} / \mathrm{K}^{+}$-ATPase maintains $\mathrm{Na}^{+}$and $\mathrm{K}^{+}$concentration gradients across the membrane. The major route for $\mathrm{Cl}^{-}$exit across the apical membrane in the normal murine intestine is via the cystic fibrosis transmembrane conductance regulatory protein, $\mathrm{CFTR}, \mathrm{Cl}^{-}$channel [5-7]. In the $o b / o b$ mouse jejunum, the role of CFTR and the contribution of key intestinal epithelial transporters towards chloride secretory function remains relatively unclear. Aside from our initial published findings [8], indicating a reduced basal jejunal $\mathrm{I}_{\mathrm{sc}}$ in $o b / o b$ mouse jejunum (due to reductions in: CFTR expression, activity of the basolateral $\mathrm{K}_{\mathrm{Ca}}$ channel and $\mathrm{Na}^{+} / \mathrm{K}^{+}$-ATPase) there have been no further studies determining the relevance of a reduced $\mathrm{Cl}^{-}$secretory function to the $o b / o b$ mouse, nor any studies aimed at improving this deficiency.

Genistein, a naturally occurring (found in soy) phytoestrogen [9], is a widely recognized CFTR activator, both in isolated cells $[10,11]$ and tissues [12-14]. We have previously shown that C57BL/6J lean mice fed a genistein-containing diet (600 $\mathrm{mg}$ genistein $/ \mathrm{kg}$ diet) for 4-weeks yield serum genistein levels of $\sim 4-7 \mu \mathrm{M}$ in male and female mice [13]. Such serum genistein levels are comparable to humans consuming a soy milk diet [15]. We have previously demonstrated that dietary exposure to genistein (600 mg genistein $/ \mathrm{kg} \mathrm{diet)} \mathrm{for} \mathrm{a}$ 4 -week period generated significant stimulation in basal $\mathrm{I}_{\mathrm{sc}}$ across freshly isolated segments of jejunum from female lean mice. Modification of tissue function by genistein has also been examined in duodenum, whereby genistein has been shown to stimulate increased $\mathrm{HCO}_{3}{ }^{-}$ secretion via an ER/PI3K-mediated pathway $[16,17]$.

The major objective of this study was to ascertain whether dietary genistein would result in improved secretory function in this diabetic model. To that end, we investigated the $I_{s c}$ using several pharmacological modulators, and evaluated expression of key proteins involved in the chloride secretory function of jejunum. In this study, we provide data to suggest that jejunal basal $\mathrm{I}_{\mathrm{sc}}$ is reduced in the $o b / o b$ mouse directly due to reductions in: CFTR expression (in both males and females), NKCC1 expression (in males), reduced activity of both basolateral $\mathrm{K}_{\mathrm{Ca}}$ channel and $\mathrm{Na}^{+} / \mathrm{K}^{+}$-ATPase (in both males and females). We provide the first evidence to demonstrate that consuming a genistein diet ( $600 \mathrm{mg}$ genistein $/ \mathrm{kg}$ diet) has beneficial effects on basal $\mathrm{I}_{\mathrm{sc}}$ (returning it back to levels measured in leans) which is mediated in females by an increase in the $\mathrm{K}_{\mathrm{Ca}}$-sensitive $\mathrm{I}_{\mathrm{sc}}$, whereas in males, it is mediated by an increase in $\mathrm{Na}^{+} / \mathrm{K}^{+}$-ATPase activity and NKCC1 expression. Of note, the phosphodiesterase enzyme (PDE) inhibitor IBMX, had a significant inhibitory effect in $o b / o b$ females (not in males) and genistein diet reversed this. Further evaluation with milrinone suggested PDE3 is likely dysregulated in $o b / o b$ females, and is reversed by genistein diet.

Improved understanding of the intestinal dysfunctions in the $o b / o b$ jejunum, may allow for the development of novel drug targets to treat the intestinal complications associated with diabetes. 


\section{Cellular Physiology Cell Physiol Biochem 2016;40:335-346 \begin{tabular}{l|l|l} 
and Biochemistry $10.1159 / 000452549$ & $\begin{array}{l}\text { Do 2016 The Author(s). Published by S. Karger AG, Basel } \\
\text { Published online: November 21, } 2016\end{array}$ \\
www.karger.com/cpb
\end{tabular} \\ Catmull et al.: Basal $\mathrm{Cl}^{-}$Secretion Increased by Genistein in $\mathrm{Ob} / \mathrm{Ob}$ Murine Jejunum}

\section{Materials and Methods}

Mouse model of obesity

Both sexes of $o b / o b$ and lean C57BL/6J mice (4-5 weeks old) were purchased from Jackson Laboratory (Bar Harbor, ME). Mice were randomly divided into two diet groups: standard rodent diet Harlan 5001 (std), or genistein-enriched diet (600 mg genistein/kg diet, 600G) and given food and water ad libitum. The male and female $o b / o b$ and lean mice were housed in an animal care facility with 12:12-hour light-dark cycle. Each week, body weight and overall health was examined. At $\sim 12$ weeks of age, mice were euthanized by asphyxiation in an atmosphere of $100 \% \mathrm{CO}_{2}$, followed immediately by surgical thoracotomy (thus inducing pneumothorax). Animal care was conducted in accordance with established guidelines, and all protocols were approved by the Midwestern University Institutional Animal Care and Use Committee.

\section{Histology and morphology}

Freshly isolated pieces of jejunum were embedded and flash frozen in Optimal Cutting Temperature compound (O.C.T., Tissue-Tek, Torrance, CA). For hematoxylin and eosin (H \& E) staining, frozen sliced sections $(8-10 \mu \mathrm{m})$ of jejunum were stained with a standard protocol (as previously published, [8]). Crypt depth was measured using Axiovision (Carl Zeiss), from images of $\mathrm{H}$ \& E stained jejunum sections. All images were taken at 10x magnification. Averages of measurements were taken from 5 separate slices per frozen section of jejunum (i.e. per mouse) and data are presented as the average of multiple mice per group.

\section{CFTR, NKCC1 and $\mathrm{Na}^{+} / \mathrm{K}^{+}$-ATPase Western blot analysis}

At collection, jejuna were immediately snap frozen in liquid nitrogen and stored at $-80^{\circ} \mathrm{C}$. Jejuna were later prepared for western blot analysis by homogenization, and the western blot protocol used was similar to that described previously $[8,18]$. Blots were incubated with primary antibody to CFTR [CF3] $(1: 1000$, Abcam Cambridge, MA), NKCC1 (1:1000, TEFS2, generous gift from Dr. Christian Lytle, University California Riverside), and Na/K-ATPase (1:1000, Cell Signaling, Danvers, MA) overnight at $4^{\circ} \mathrm{C}$. After washing, blots were incubated with secondary antibody, anti-rabbit IgG $(\mathrm{H}+\mathrm{L})$ Dylight $(1: 15,000$, Thermo Scientific, Rockford, IL), for 1 hour at room temperature. To re-probe for actin, blots were incubated with anti-actin primary antibody (1:4000, Thermo Scientific, Rockford, IL) for 1 hour at room temperature. Blots were washed and then re-incubated with the appropriate secondary antibody anti-mouse IgG (H+L) (1:15000, Dylight, Thermo Scientific Rockford, IL). Images of membranes were taken with all proteins of interest normalized to Actin. Band density was analyzed using Odyssey-Clx (LI-COR, Lincoln, NE) and Image Studio (LI-COR, Lincoln, NE).

\section{Bioelectric measurement of intestinal secretion}

Short circuit current measures were as described previously [18, 19]. Transepithelial short circuit current $\left(\mathrm{I}_{\mathrm{sc}}, \mu \mathrm{A} / \mathrm{cm}^{2}\right)$ of $0.3 \mathrm{~cm}^{2}$ exposed surface area of jejunum was measured via an automatic voltage clamp (VCC-600, Physiologic Instruments, San Diego, CA) and the experimental conditions and methods were as previously described $[18,19]$. In order to reduce the tissue exposure to endogenously generated prostanoids resulting from tissue manipulation, all tissues were maintained in $1 \mu \mathrm{M}$ indomethacin [20]. In order to avoid an inward current due to $\mathrm{Na}^{+}$-coupled glucose transport glucose $(10 \mathrm{mM})$ was added to the serosal KBR bath and mannitol (10 mM) substituted for glucose in the mucosal KBR bath[21]. To minimize variations in intrinsic intestinal neural tone [22] and to limit the absorptive capacity of the mucosa, the serosal side of the tissues were exposed to tetrodotoxin $(0.1 \mu \mathrm{M})$.

Experimental protocols. Tissues were exposed to KBR (20 min) and steady-state basal $\mathrm{I}_{\mathrm{sc}}$ measured at that time. In a set of tissues we added forskolin (10 $\mu \mathrm{M}$, bilateral) until steady-state was achieved at time 20 minutes, then bumetanide $(100 \mu \mathrm{M}$, serosal) for 10 minutes, acetazolamide for 10 minutes $(100 \mu \mathrm{M}$, bilateral). Alternatively, in another set of tissues following attaining steady-state basal $\mathrm{I}_{\mathrm{sc}}$ there was addition of the following pharmacological tools for 15 minutes: 4,4'-diisothiocyanatostilbene-2,2'-disulfonic acid disodium salt hydrate (DIDS, $200 \mu \mathrm{M}$, bilateral), or clotrimazole $(100 \mu \mathrm{M}$, bilateral), or ouabain $(100 \mu \mathrm{M}$, basolateral) were used to determine the contribution to the anion secretory component by $\mathrm{Ca}^{2+}$-activated $\mathrm{Cl}^{-}$channels, $\mathrm{Ca}^{2+}$-activated $\mathrm{K}^{+}$channels, and the $\mathrm{Na}^{+} / \mathrm{K}^{+}$-ATPase, respectively. The concentrations of DIDS, clotrimazole, bumetanide and acetazolamide were as used previously $[8,18]$. The concentration of 


\section{Cellular Physiology Cell Physiol Biochem 2016;40:335-346 \\ \begin{tabular}{ll|l} 
and Biochemistry & Dublished online: November 21, 2016 & $\begin{array}{l}\text { (c) } 2016 \text { The Author(s). Published by S. Karger AG, Basel } \\
\text { www.karger.com/cpb }\end{array}$ \\
\hline
\end{tabular}}

Catmull et al.: Basal $\mathrm{Cl}^{-}$Secretion Increased by Genistein in $\mathrm{Ob} / \mathrm{Ob}$ Murine Jejunum

clotrimazole used is within the range of doses used in the literature (from $10 \mu \mathrm{M}$ in colonic T84 cells [23], to $30 \mu \mathrm{M}$ in human rectal tissue [24], to $150 \mu \mathrm{M}$ in murine jejunum [25]. Glucose (10 mM, mucosal) was added at the end of each experiment to stimulate $\mathrm{Na}^{+}$-coupled glucose transport, as an assessment of tissue viability (denoted by $>10 \%$ increase in $\mathrm{I}_{\mathrm{sc}}$ ). Tissues failing to respond to glucose within this parameter were discarded. In a subset of experiments, jejunum segments were exposed to the following phosphodiesterase inhibitors (100 $\mu \mathrm{M}$ for 10 minutes, and $200 \mu \mathrm{M}$ for an additional 10 minutes, bilateral): milrinone, rolipram, and 8-methoxymethyl-3-isobutyl-1-methylxanthine (IBMX).

Solutions. $\mathrm{Cl}^{-}$-containing KBR contained the following (in mM): $115 \mathrm{NaCl}, 25 \mathrm{NaHCO}_{3}, 5 \mathrm{KCl}, 1.2 \mathrm{MgCl}_{2}$ and $1.2 \mathrm{CaCl}_{2}$, $\mathrm{pH} 7.4$.

Chemicals. DIDS was purchased from Calbiochem (San Diego, CA). Clotrimazole was purchased from MP Biomedicals (Solon, OH). Ouabain was purchased from R\&D Systems (Minneapolis, MN). All other chemicals were obtained from Sigma Chemical Co. (St. Louis, MO).

Statistics

Data are expressed as mean \pm SEM. Numbers in parentheses represent numbers of tissues used from separate individual mice. One-way ANOVA with Neuman-Keul's multiple comparison test was performed using GraphPad (San Diego, CA) and $P<0.05$ was considered statistically significant.

\section{Results}

Ussing chamber bioelectric measurements

In order to identify the effects of dietary genistein on jejunum epithelial short circuit current (transepithelial $\mathrm{Cl}^{-}$secretion, $\mathrm{I}_{\mathrm{sc}}$ ) we examined freshly excised jejunum in the absence and presence of agonist stimulation. As shown in Fig. 1A, C, basal $\mathrm{I}_{\mathrm{sc}}$ was significantly decreased in $o b / o b$ female mice $\left(78.5 \pm 6.4 \mu \mathrm{A} / \mathrm{cm}^{2}, \mathrm{n}=7, P<0.05\right)$ compared to lean controls $\left(117.2 \pm 15.9 \mu \mathrm{A} / \mathrm{cm}^{2}, \mathrm{n}=7\right)$, and genistein reversed this $\left(128.9 \pm 19.8 \mu \mathrm{A} / \mathrm{cm}^{2}, \mathrm{n}=8, P<0.05\right)$. Basal $I_{\text {sc }}$ was similarly significantly decreased in $o b / o b$ male mice $\left(50.5 \pm 9.6 \mu \mathrm{A} / \mathrm{cm}^{2}, \mathrm{n}=\right.$ $5, P<0.05)$ compared to lean controls $\left(95.2 \pm 20.4 \mu \mathrm{A} / \mathrm{cm}^{2}, \mathrm{n}=4\right)$, and genistein reversed this $\left(109.0 \pm 9.4 \mu \mathrm{A} / \mathrm{cm}^{2} \mathrm{n}=7, P<0.05\right.$, Fig. $\left.1 \mathrm{~B}, \mathrm{C}\right)$. The cAMP-stimulated $\mathrm{I}_{\mathrm{sc}}$ was assessed following application of forskolin (bilateral, $10 \mu \mathrm{M}$, Fig. 1A, 1B, D) and was comparable between all three groups in both sexes (despite a trend for decreased cAMP-stimulated $\mathrm{I}_{\mathrm{sc}}$ in the $o b / o b$ standard-fed female mice compared to their lean controls). There was no change in the bumetanide-sensitive $I_{s c}$ between any of the groups for either sex (Fig. 1A, 1B, E). There was no change in the acetazolamide-sensitive $\mathrm{I}_{\mathrm{sc}}$ between any of the female groups (Fig. 1F), however, genistein-diet significantly decreased the acetazolamide-sensitive $\mathrm{I}_{\mathrm{sc}}$ in $o b / o b$ males $(7.3 \pm 0.8 \%, \mathrm{n}=7, P<0.05)$ compared to those $o b / o b$ males fed-standard chow $(18.7 \pm 4.7 \%, \mathrm{n}=5)$. These data suggest that the decreased jejunum basal $\mathrm{I}_{\mathrm{sc}}$ in the diabetic $o b / o b$ model is reversed by dietary genistein.

To better assess the role of key epithelial ion channels and transporters that may contribute towards the basal $\mathrm{I}_{\mathrm{sc}}$, the effects of three pharmacological inhibitors applied for a period of $15 \mathrm{~min}$ were examined. Application of clotrimazole (bilateral $100 \mu \mathrm{M}$, Fig. 2A), a $\mathrm{Ca}^{2+}$-activated $\mathrm{K}^{+}$channel blocker $[19,26,27]$, resulted in significantly less $\%$ inhibition in the $o b / o b$ female mice $(-12.1 \pm 5.2 \%, \mathrm{n}=9, P<0.05)$ compared to lean controls $(11.2 \pm 4.2 \%$, $\mathrm{n}=7)$, and genistein diet reversed this $(9.2 \pm 3.9 \%, \mathrm{n}=9)$. Clotrimazole application also resulted in significantly less $\%$ inhibition in the $o b / o b$ male mice $(-1.7 \pm 4.6 \%, \mathrm{n}=6, P<0.05)$ compared to lean controls $(9.8 \pm 2.8 \%, \mathrm{n}=8)$, and genistein diet had no effect $(-2.8 \pm 8.3 \%$, $\mathrm{n}=7$, Fig. 2A). Application of DIDS (bilateral $200 \mu \mathrm{M}$ ) a Ca ${ }^{2+}$-activated $\mathrm{Cl}^{-}$channel inhibitor, resulted in comparable, non-significant, \% inhibition between all groups of male and female mice. DIDS inhibition in $o b / o b$ female mice $(-12.4 \pm 1.8 \%, \mathrm{n}=7)$ was similar to lean controls $(-5.2 \pm 7.2 \%, \mathrm{n}=7)$, and genistein had no effect $(-4.9 \pm 6.7 \%, \mathrm{n}=8)$. DIDS inhibition in $o b /$ $o b$ male mice $(-7.8 \pm 3.8 \%, \mathrm{n}=5)$ was similar to lean controls $(-15.4 \pm 5.7 \%, \mathrm{n}=6)$, and genistein had no effect $(-12.3 \pm 14.2 \%, \mathrm{n}=6)$. Application of ouabain, a $\mathrm{Na}^{+} / \mathrm{K}^{+}$-ATPase pump inhibitor (serosal $100 \mu \mathrm{M}$, Fig. 2B), resulted in significantly less \% inhibition of basal $\mathrm{I}_{\mathrm{sc}}$ in 
Fig. 1. Effect of genistein on $I_{\mathrm{sc}^{\circ}}$ (A) Average raw trace data of recordings from jejunum from female mice ( $\mathrm{n}=7-8 /$ group). (B) Average raw trace data of recordings from jejunum from male mice ( $\mathrm{n}=4-7 /$ group). Leans-standard diet $(\Delta), o b /$ $o b$-standard diet $(0), o b / o b$ genistein diet $(\bullet)$. Basal $\mathrm{I}_{\mathrm{sc}}$ recorded from time 0-20 mins, forskolin (10 $\mu \mathrm{M}$, bilateral) added at time 20 mins, bumetanide $(100 \mu \mathrm{M}$, basolateral $)$ added at 40 mins, acetazolamide (100 $\mu \mathrm{M}$, bilateral) added at time 50 mins and glucose $(10 \mathrm{mM}, \mathrm{bi}-$ lateral) added at time 60 mins. (C) Average basal $\mathrm{I}_{\mathrm{sc}}$ (D) Average increase in $\mathrm{I}_{\mathrm{sc}}$ with forskolin (10 $\mu \mathrm{M}$, bilateral). (E) Average inhibition in $\mathrm{I}_{\mathrm{sc}}$ with bumetanide (100 $\mu \mathrm{M}$, basolateral). (F) Average inhibition in $I_{s c}$ with acetazolamide $(100 \mu \mathrm{M}$, bilateral. Values are means \pm SEM (n
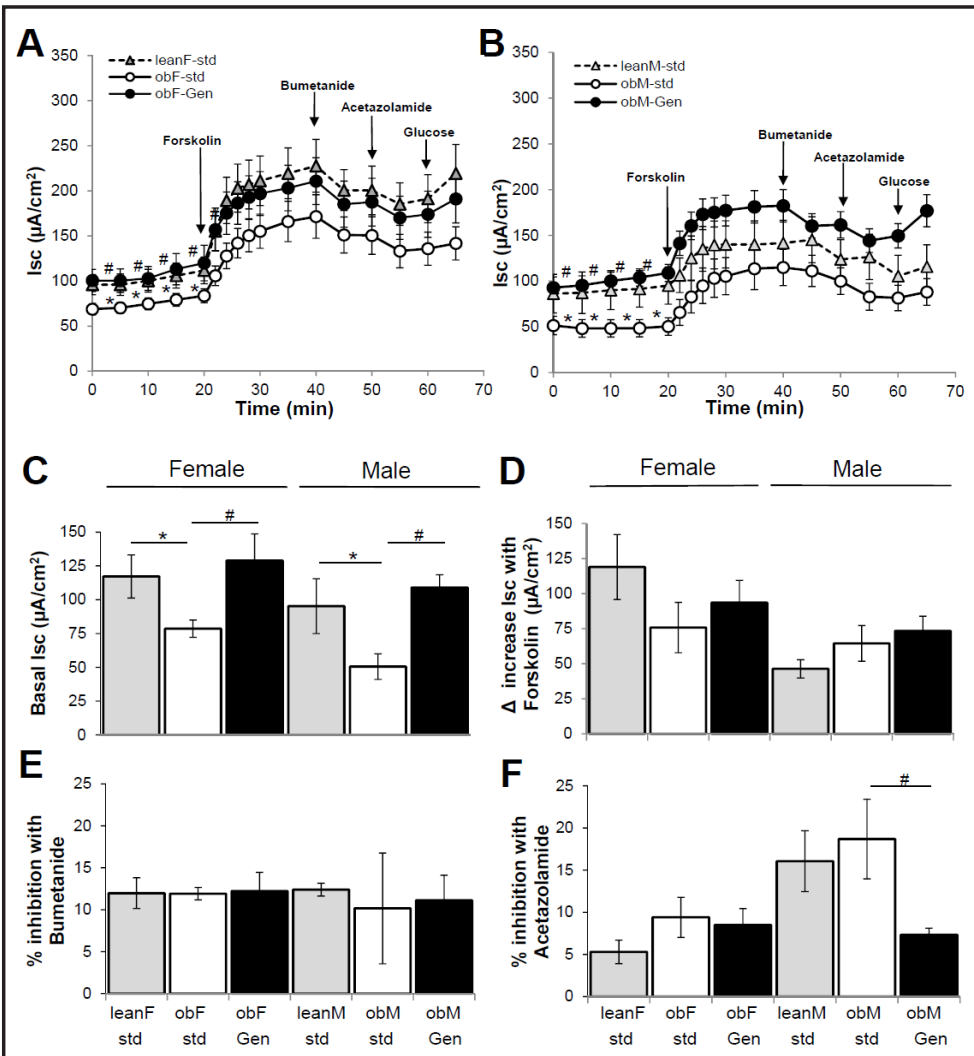

$=4-8$ /group). ${ }^{*}$ denotes $P<0.05$, statistical difference to lean controls, and ${ }^{\#}$ denotes $P<0.05$, statistical genistein-mediated effect.

$o b / o b$ female mice $(-0.7 \pm 6.2 \%, \mathrm{n}=7, P<0.05)$ compared to lean controls $(30.9 \pm 9.1 \%, \mathrm{n}=$ $6)$, and was without effect by genistein-diet $(6.1 \pm 5.0 \%, n=8)$. Ouabain application in males resulted in significantly less \% inhibition of the basal $\mathrm{I}_{\mathrm{sc}}$ in $o b / o b$ male mice $(3.9 \pm 4.1 \%, \mathrm{n}=$ $6, P<0.05)$ compared to lean controls $(13.0 \pm 2.5 \%, \mathrm{n}=12)$, and was reversed by genisteindiet $(45.4 \pm 12.6 \%, \mathrm{n}=6$, Fig. $2 \mathrm{~B})$. These data suggest that the deficit in $\mathrm{Ca}^{2+}$-activated $\mathrm{K}^{+}$ channel activity noted in female and male leptin-deficient mice is reversed by genistein-diet in females only (not males), however the deficit in $\mathrm{Na}^{+} / \mathrm{K}^{+}$-ATPase inhibition noted in both female and male $o b / o b$ mice is reversed by genistein-diet in males only (not females).

CFTR activation is via a cAMP-dependent pathway, and cellular levels of cAMP are controlled by a balance of cAMP production (via adenylate cyclase), and degradation (via phosphodiesterases, PDE's). Therefore, we examined whether disturbances in the activities of PDE's (via hydrolysis of cAMP and/or cGMP) could contribute towards either the observed decrease in basal $\mathrm{I}_{\mathrm{sc}}$ in $o b / o b$ mouse jejunum, or the genistein-mediated increase in $\mathrm{I}_{\mathrm{sc}^{\prime}}$ we examined the effects of various isoforms of PDE's: IBMX, EHNA, milrinone, and rolipram. The non-specific PDE, IBMX (bilateral $200 \mu \mathrm{M}$ ) significantly increased basal $\mathrm{I}_{\mathrm{sc}}$ in jejunum from control female $o b / o b$ mice (delta change in $\mathrm{I}_{\mathrm{sc}}=84.8 \pm 21.5 \mu \mathrm{A} / \mathrm{cm}^{2}, \mathrm{n}=8, P<0.05$ ), compared to leans, which was reversed in genistein-fed $o b / o b$ female mice (delta change in $I_{s c}=22.5 \pm 3.7 \mu \mathrm{A} / \mathrm{cm}^{2}, \mathrm{n}=12$, Fig. 3A). EHNA, a selective blocker of PDE2 (bilateral $200 \mu \mathrm{M}$ ), did not have an effect on jejunal basal $\mathrm{I}_{\mathrm{sc}}$ from female $o b / o b$ control mice (delta change in $\mathrm{I}_{\mathrm{sc}}$ $=9.1 \pm 6.7 \mu \mathrm{A} / \mathrm{cm}^{2}, \mathrm{n}=7$ ) or male $o b / o b$ control mice (delta change in $\mathrm{I}_{\mathrm{sc}}=3.6 \pm 2.6 \mu \mathrm{A} / \mathrm{cm}^{2}$, $\mathrm{n}=7$ ). Neither was there an effect of EHNA on jejunal basal $\mathrm{I}_{\mathrm{sc}}$ from female genistein-treated $o b / o b$ mice (delta change in $\mathrm{I}_{\mathrm{sc}}=-12.3 \pm 6.8 \mu \mathrm{A} / \mathrm{cm}^{2}, \mathrm{n}=4$ ) or male genistein-treated $o b /$ $o b$ mice (delta change in $\mathrm{I}_{\mathrm{sc}}=-1.6 \pm 1.3 \mu \mathrm{A} / \mathrm{cm}^{2}, \mathrm{n}=6$ ). Rolipram, a selective PDE4 inhibitor (bilateral $200 \mu \mathrm{M}$ ) had no effect on basal $\mathrm{I}_{\mathrm{sc}}$ in male or female $o b / o b$ mice (Fig. 3B). Milrinone, a selective PDE3 inhibitor (bilateral $200 \mu \mathrm{M}$ ) significantly increased basal $\mathrm{I}_{\mathrm{sc}}$ in jejunum from 
Fig. 2. Effect of pharmacological inhibitors on the basal jejunum $\mathrm{I}_{\text {sc }}$ (A) Average percent inhibition of basal $I_{s c}$ by clotrimazole $(100 \mu \mathrm{M}$, bilateral), on lean mice (gray bars), $o b / o b$ mice fed standard diet (open bars) and $o b$ / $o b$ mice fed genistein diet (solid bars). $\mathrm{n}=6-9$ /group. Upper panel is average $I_{s c}$ traces (arrows indicate time of clotrimazole administration). (B) Average percent inhibition of basal $\mathrm{I}_{\mathrm{sc}}$ by ouabain $(100 \mu \mathrm{M}$, basolateral), on lean mice (gray bars), $o b / o b$ mice fed standard diet (open bars) and $o b / o b$ mice fed genistein diet (solid bars). $\mathrm{n}$ = 6-12/group. Upper panel is average $I_{\text {sc }}$ traces (arrows indicate time of clotrimazole administration). Values are means \pm SEM. * denotes $P<0.05$, statistical difference to lean controls, and " denotes $P<0.05$, statistical genistein-mediated effect.

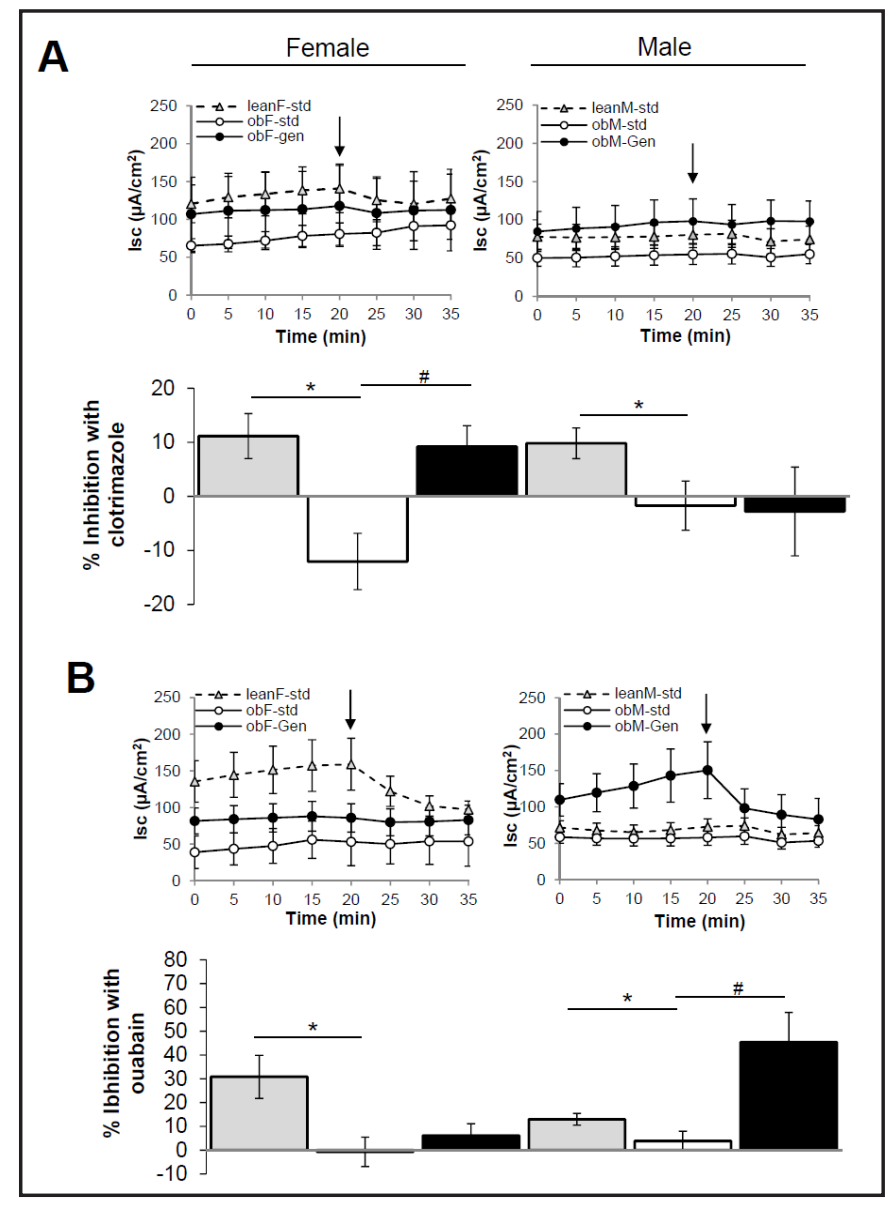

control female $o b / o b$ mice (delta change in $\mathrm{I}_{\mathrm{sc}}=65.1 \pm 16.4 \mu \mathrm{A} / \mathrm{cm}^{2}, \mathrm{n}=8, P<0.05$ ), compared to leans, which was reversed in genistein-fed $o b / o b$ female mice (delta change in $\mathrm{I}_{\mathrm{sc}}=17.3 \pm$ $3.7 \mu \mathrm{A} / \mathrm{cm}^{2}, \mathrm{n}=14$, Fig. $3 \mathrm{C}$ ). These data suggest that inhibition of a PDE3-dependent pathway plays a role in $o b / o b$ females but not in males.

\section{Jejunum Morphology}

In theory, modifications in jejunum crypt dimensions, i.e. reduced crypt depth, could provide less available secretory epithelial cells, and could have partially explained the decreased basal $\mathrm{I}_{\mathrm{sc}}$ in $o b / o b$ jejunum. Therefore, we determined whether effects on jejunal basal $\mathrm{I}_{\mathrm{sc}}$ were associated with changes in morphology. Histological sections were stained using H \& E and analyzed for crypt depth. There was no change in crypt depth in the $o b /$ $o b$ female group $(89.11 \pm 3.76 \mu \mathrm{m}, \mathrm{n}=15)$ compared to lean controls $(87.36 \pm 6.62 \mu \mathrm{m}$, $\mathrm{n}=15)$ and genistein-diet was without effect $(80.13 \pm 4.09 \mu \mathrm{m}, \mathrm{n}=14)$. Similarly there were no changes in crypt depth in the male groups: ob/ob males $(83.83 \pm 2.92 \mu \mathrm{m}, \mathrm{n}=17)$ compared to lean controls $(91.26 \pm 6.16 \mu \mathrm{m}, \mathrm{n}=12)$ and genistein-diet was without effect $(86.71 \pm 42.99 \mu \mathrm{m}, \mathrm{n}=13)$. These data suggest that structural changes i.e. alterations in crypt dimensions are not responsible for either the reduced basal $\mathrm{I}_{\mathrm{sc}}$ noted in $o b / o b$ mice, or the genistein-mediated rescue of this $I_{s c}$.

\section{Total CFTR, NKCC1 and $\mathrm{Na}^{+} / \mathrm{K}^{+}$-ATPase protein expression}

Small intestinal $\mathrm{Cl}^{-}$secretion at the crypts requires the following; $\mathrm{Cl}^{-}$entrance into epithelial cells via the $\mathrm{Na}^{+} / \mathrm{K}^{+} / 2 \mathrm{Cl}^{-}$(NKCC1) co-transporter, and activation of both apical $\mathrm{Cl}^{-}$channels (CFTR) and basolateral $\mathrm{K}^{+}$channels (to maintain the driving force for $\mathrm{Cl}^{-}$exit across the apical membrane), and $\mathrm{Na}^{+} / \mathrm{K}^{+}$-ATPase (to maintain $\mathrm{Na}^{+}$and $\mathrm{K}^{+}$concentration gradients across the membrane). Since, CFTR chloride channels provide the major route 
Fig. 3. Effect of phosphodiesterase inhibitors on the basal jejunum $I_{s c}$ (A) Average percent inhibition of basal $\mathrm{I}_{\mathrm{sc}}$ by IBMX (200 $\mu \mathrm{M}$, bilateral), on lean mice (gray bars), $o b / o b$ mice fed standard diet (open bars) and $o b / o b$ mice fed genistein diet (solid bars). $\mathrm{n}=6-12$ /group. (B) Average percent inhibition of basal $\mathrm{I}_{\mathrm{sc}}$ by rolipram $(200 \mu \mathrm{M}$, bilateral), on lean mice (gray bars), ob/ob mice fed standard diet (open bars) and $o b / o b$ mice fed genistein diet (solid bars). $n=6-14$ /group. (C) Average percent inhibition of basal $\mathrm{I}_{\mathrm{sc}}$ by milrinone (100 $\mu \mathrm{M}$, basolateral), on lean mice (gray bars), $o b / o b$ mice fed standard diet (open bars) and $o b / o b$ mice fed genistein diet (solid bars). $n=5-14 /$ group. Values are means \pm SEM. * denotes $P<0.05$, statistical difference to lean controls, and " denotes $P<$ 0.05 , statistical genistein-mediated effect.

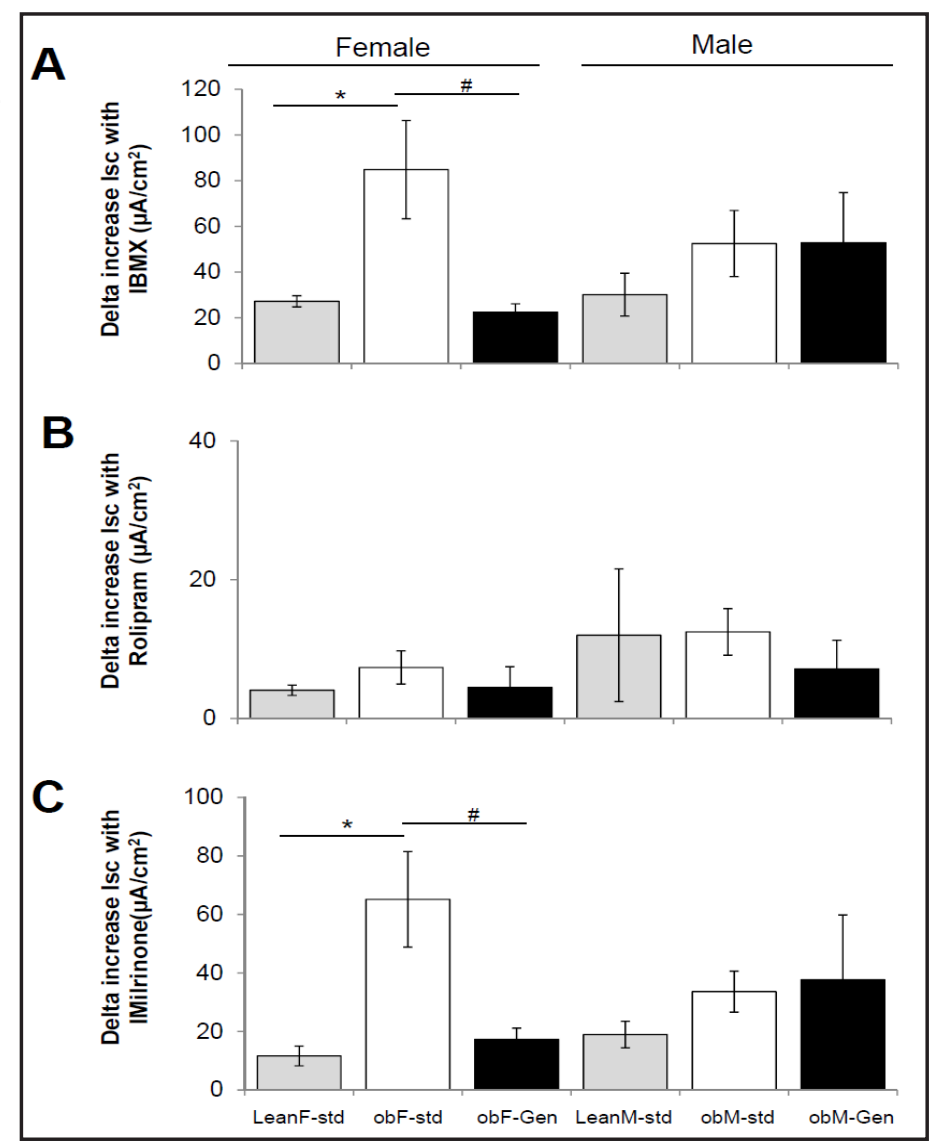

for chloride secretion into the jejunum lumen, we determined total CFTR protein present utilizing standard western blot techniques [18, 28-30]. We confirmed a single band with the expected molecular weight of $\sim 170 \mathrm{kD}$ for CFTR. We have had success with identifying CFTR expression with this antibody in wild type (lean) murine jejunum [18] and jejunum from ob/ob mice [8], and other studies have demonstrated successful use of this antibody to detect CFTR within airway epithelium [31]. Total CFTR protein expression normalized to actin (Fig. $4 \mathrm{~A})$ was significantly decreased $(\sim 80 \%)$ in the ob/ob female mice $(0.07 \pm 0.05, \mathrm{n}$ $=6, P<0.05)$ compared to lean counterparts $(0.49 \pm 0.12, \mathrm{n}=8)$. Genistein-diet had no effect on CFTR expression in female $o b / o b$ mice $(0.11 \pm 0.06, \mathrm{n}=7)$. Total CFTR protein expression normalized to actin (Fig. 4A) was significantly decreased (by a comparable $\sim 80 \%$ ) in the $o b / o b$ male mice $(0.14 \pm 0.0,3 \mathrm{n}=7, P<0.05)$ compared to leans $(0.74 \pm 0.27, \mathrm{n}=8)$, and genistein-diet similarly had no effect on CFTR expression $(0.06 \pm 0.04, \mathrm{n}=7)$.

To assess additional potential contributors towards the reduced jejunum secretory process in the $o b / o b$ mice compared to lean counterparts, we evaluated total protein expression of NKCC1, and $\mathrm{Na}^{+} / \mathrm{K}^{+}$-ATPase. As shown in Fig. 4B, NKCC1 protein expression, was comparable in the $o b / o b$ female mice $(0.57 \pm 0.15, \mathrm{n}=7)$ compared to their lean counterparts $(0.50 \pm 0.15, \mathrm{n}=9)$, and genistein-diet had no effect $(0.38 \pm 0.15, \mathrm{n}=9)$. NKCC1 protein expression was significantly reduced in the $o b / o b$ male mice $(0.07 \pm 0.02, \mathrm{n}=7)$ compared to lean controls $(0.30 \pm 0.11, \mathrm{n}=9)$, and genistein-diet reversed this $(0.30 \pm 0.14$, $\mathrm{n}=9, P<0.05$, Fig. 4B). Expression of total $\mathrm{Na}^{+} / \mathrm{K}^{+}$-ATPase protein was comparable in female $o b / o b$ mice and female lean controls $(0.29 \pm 0.08, \mathrm{n}=11$, and $0.18 \pm 0.07, \mathrm{n}=10$, respectively Fig. 4C), and genistein-diet was without effect $(0.41 \pm 0.13, \mathrm{n}=11)$. Expression of total $\mathrm{Na}^{+} / \mathrm{K}^{+}$-ATPase protein was comparable in $o b / o b$ males, leans, and those $o b / o b$ males fed genistein-diet $(0.55 \pm 0.16(n=9), 0.28 \pm 0.12(n=9)$, and $0.49 \pm 0.11(n=10)$ respectively Fig. 4C). These data suggest that expression of total CFTR was significantly decreased $\sim 80 \%$ $(P<0.05)$ in male and female $o b / o b$ mice versus leans, and genistein-diet was without effect, 
Fig. 4. Total CFTR, NKCC1 and $\mathrm{Na}^{+} / \mathrm{K}^{+}-\mathrm{AT}-$ Pase protein expression in murine jejunum. (A) Typical western blot demonstrating CFTR expression (normalized to actin) in jejunum from $o b / o b$ and lean mice. CFTR and actin bands were observed at $168 \mathrm{KDa}$ and $43 \mathrm{KDa}$ respectively. Average CFTR/actin ratio comparing lean (gray bars), $o b / o b$ standard diet fed (open bars) and $o b / o b$ genistein diet fed (solid bars). $\mathrm{n}=6-8 /$ group. (B) Typical western blot demonstrating NKCC1 expression (normalized to actin) in jejunum from $o b / o b$ and lean mice. NKCC1 and actin bands were observed at $160 \mathrm{KDa}$ and $43 \mathrm{KDa}$ respectively. Average NKCC1/actin ratio comparing lean (gray bars), $o b / o b$ standard diet fed (open bars) and $o b / o b$ genistein diet fed (solid bars). $n=7-9 /$ group. (C) Typical western blot demonstrating $\mathrm{Na}^{+} / \mathrm{K}^{+}$-ATPase expression (normalized to actin) in jejunum from $o b / o b$ and lean mice. $\mathrm{Na}^{+} /$ $\mathrm{K}^{+}$-ATPase and actin bands were observed at $100 \mathrm{KDa}$ and $43 \mathrm{KDa}$ respectively. Average $\mathrm{Na}^{+} / \mathrm{K}^{+}$-ATPase /actin ratio comparing lean (gray bars), $o b / o b$ standard diet fed (open bars) and $o b / o b$ genistein diet fed (solid bars). $\mathrm{n}=9-11 /$ group. Values are means \pm SEM. * denotes $P<0.05$, statistical difference to lean controls, and ${ }^{\#}$ denotes $P<0.05$, statistical genistein-mediated effect.

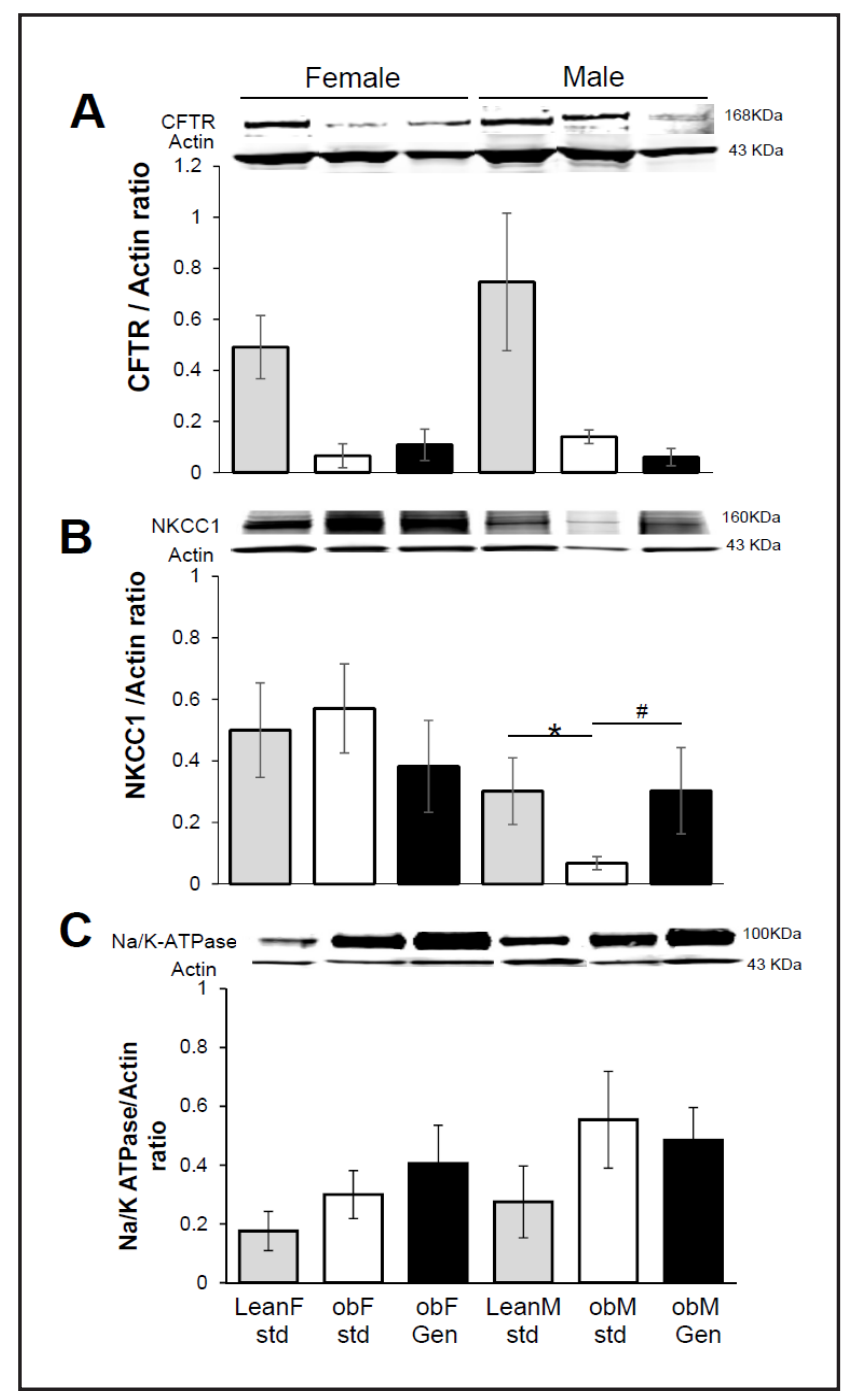

and expression of total NKCC1 (normalized to actin) was significantly decreased $\sim 80 \%$ $(P<0.05)$ in $o b / o b$ male mice versus leans, and genistein-diet reversed this.

\section{Discussion}

In murine models of diabetes the small intestine remains an understudied region. The $o b / o b$ mouse model is hypoleptinemic, hyperphagic, obese, with insulin resistance [32] and demonstrates intestinal complications that mimic those seen clinically (slowing of gastrointestinal transit [2], and gastroparesis [33]). This model of diabetes has been reported clinically [34]. The $o b / o b$ mice used in this study are 12 weeks old, consistent with use in other studies: male $o b / o b$ mice (6-15 weeks old) and male mice fed high fat diet (from 14-33 weeks) exhibit gastroparesis with continued elevated plasma glucose [35-37], and 15 week old male $o b / o b$ mice exhibit slowed gastrointestinal transit $[2,38]$.

The jejunum epithelium is the major site for fluid secretion within the small intestine. We demonstrate significant deficits in $o b / o b$ mouse jejunum that are consistent with our previously published evidence indicating decreased secretory function in this model [8]: (1) reduced small intestinal basal $\mathrm{I}_{\mathrm{sc}}$ in $o b / o b$ mice compared to leans, (2) decreased contribution of $\mathrm{Na}^{+} / \mathrm{K}^{+}$-ATPase in $o b / o b$ mice versus leans, (3) decreased contribution of $\mathrm{K}_{\mathrm{Ca}}$ in $o b / o b$ mice versus leans, and (4) decreased CFTR expression in $o b / o b$ mice versus 


\section{Cellular Physiology Cell Physiol Biochem 2016;40:335-346 \\ \begin{tabular}{ll|l} 
and Biochemistry & Dublished online: November 21, 2016 & $\begin{array}{l}\text { (c) } 2016 \text { The Author(s). Published by S. Karger AG, Basel } \\
\text { www.karger.com/cpb }\end{array}$ \\
\hline
\end{tabular}}

Catmull et al.: Basal $\mathrm{Cl}^{-}$Secretion Increased by Genistein in $\mathrm{Ob} / \mathrm{Ob}$ Murine Jejunum

leans. Our data indicate that alterations in key epithelial transporters required for normal secretory function likely contributes towards the phenotype of this model.

A decreased crypt depth, could hypothetically provide less available secretory epithelial cells, and may have partially explained the reduced basal $I_{\text {sc }}$ in $o b / o b$ mice. However, since crypt depth was comparable in $o b / o b$ and leans, we focused on the dysfunctions in transporters involved in the generation of epithelial $\mathrm{Cl}^{-}$secretion. We demonstrate that basal $\mathrm{I}_{\mathrm{sc}}$ across the $o b / o b$ mouse jejunum was significantly reduced in both male and female $o b / o b$ mice, and this was accompanied by a $\sim 6$-fold loss of CFTR expression [8]). Interestingly, whilst genistein diet returned the reduced basal $\mathrm{I}_{\mathrm{sc}}$ of $o b / o b$ mice (both sexes) to levels of lean mice, this was not due to a change in CFTR expression, which remained diminished. CFTR activation is via a cAMP-dependent pathway, and cellular levels of cAMP are controlled by a balance of cAMP production and degradation (via phosphodiesterases, PDE's). Inhibition of PDE1, and PDE3 in T84 colonic cells stimulates $\mathrm{Cl}^{-}$secretion [39]. Within murine intestine, the presence of PDE1 (calcium/calmodulin-dependent), PDE3 (cGMP inhibited), PDE4 (cAMP-specific), and PDE5 (cGMP-specific) have been noted, and the inhibition of each has resulted in increased jejunal $I_{s c}[40]$. In guinea pig lungs, genistein has been shown to inhibit PDE's 1-4 [41, 42]. Acute application of genistein to murine jejunum, reduced the effect of milrinone on $\mathrm{I}_{\mathrm{sc}^{\prime}}$ suggesting that genistein activated $\mathrm{Cl}^{-}$secretion by inhibition of a PDE3-dependent pathway (PDE3 can hydrolyze both cAMP and cGMP) [14]. Our data supports those findings in $o b / o b$ female mice, and with chronic application of genistein diet (4-weeks), basal $\mathrm{I}_{\mathrm{sc}}$ is elevated (mimicking that of leans) yet interestingly, this does not appear to be a pathway in $o b / o b$ males.

Here, as with our earlier observations [8] we found no role for the $\mathrm{Ca}^{2+}$-activated $\mathrm{Cl}^{-}$ channel, (no effect of DIDS) in ob/ob mice [18]. Secretion from intestinal crypts also involves the activation of clotrimazole-sensitive basolateral $\mathrm{K}_{\mathrm{Ca}}$ channels $\left.[18,23,43]\right)$. Our data indicate that the contribution of basolateral $\left(\mathrm{K}_{\mathrm{Ca}}\right)$ channels towards murine jejunum basal $\mathrm{I}_{\mathrm{sc}}$ is reduced in $o b / o b$ mice. Interestingly, genistein diet rescued this in female $o b / o b$ mice but not in males. We have previously noted sex-dependent mechanisms of action of genistein in ovariectomized mice [44]. The $\mathrm{Na}^{+} / \mathrm{K}^{+}$-ATPase is required for optimal jejunal crypt secretion. Inhibition of the $\mathrm{Na}^{+} / \mathrm{K}^{+}$-ATPase with ouabain suggested that the contribution of $\mathrm{Na}^{+} / \mathrm{K}^{+}$-ATPase towards basal $\mathrm{I}_{\mathrm{sc}}$ was less in $o b / o b$ mice. Genistein diet rescued the loss of ouabain-sensitive $I_{\text {sc }}$ in male mice without altering expression of $\mathrm{Na}^{+} / \mathrm{K}^{+}$-ATPase. Within the jejunum the $\mathrm{Na}^{+} / \mathrm{K}^{+}$-ATPase generates a sodium gradient which drives glucose absorption. Our data is not consistent with Serhan et al. [45], demonstrating that insulin increases glucose uptake with reductions in $\mathrm{Na}^{+} / \mathrm{K}^{+}$-ATPase expression, and increased expression of SGLT1 in Caco-2 cells and rat jejunum. The NKCC1 co-transporter is the pathway for $\mathrm{Cl}^{-}$ entry into jejunum epithelium. Here, we note that bumetanide-sensitive $\mathrm{I}_{\mathrm{sc}}$ is variable in male $o b / o b$ mice (potentially reflecting the reduced total expression of NKCC1 which was reversed by genistein-diet), but was unchanged in females. Interestingly, Ueda-Nishimura et al. [46] have demonstrated that genistein and insulin synergistically stimulate insertion of NKCC1 into renal epithelial cells. Disparities in our data and other studies [46] could be attributed to: differences in cell type (renal versus jejunum, or cells versus intact tissue), the dose of genistein (low micromolar range versus $100 \mu \mathrm{M}$ ) and duration of genistein exposure (4-weeks versus acute application). The importance of sex-dependent differences is an increasing area of focus: greater expression of voltage-dependent $\mathrm{K}^{+}$channels in coronary vessels in male swine [47], reduced expression of repolarizing $\mathrm{K}^{+}$channel subunits in human female hearts [48], reduced colonic ER $\alpha$ expression in males [49].

Evidence suggests that intestinal inflammation can modify ionic transport, via changes in expression, function, or modification of the signaling pathways of $\mathrm{Na}^{+} / \mathrm{K}^{+}$-ATPase, NKCC1, sodium channels and CFTR $[50,51]$. For example, in experimental colitis, reduced colonic $\mathrm{I}_{\mathrm{sc}}$ is due to reduced chloride/bicarbonate secretion [51,52]. Indeed, TNF- $\alpha$ or IFN- $\gamma$ downregulate CFTR expression [53, 54]. Given the association of diabetes with inflammation, this fits with our quantified loss of jejunum CFTR expression in $o b / o b$ mice, and loss of NKCC1 expression in male $o b / o b$ mice, and whether or not this is linked to changes in inflammatory cytokines 


\section{Cellular Physiology Cell Physiol Biochem 2016;40:335-346 \begin{tabular}{l|l|l} 
DOI: 10.1159/000452549 & $\begin{array}{l}\text { O 2016 The Author(s). Published by S. Karger AG, Basel } \\
\text { wwww.kargercom/cpb }\end{array}$
\end{tabular} \\ Catmull et al.: Basal $\mathrm{Cl}^{-}$Secretion Increased by Genistein in $\mathrm{Ob} / \mathrm{Ob}$ Murine Jejunum}

remains to be seen. Furthermore, debate continues as to the effect of diabetes on epithelial barrier integrity: Stenman et al. [55] showed that $o b / o b$ mice had no change in gut barrier function, however, other studies suggested that the gut barrier was impaired in $o b / o b$ mice [56].

In conclusion, this study demonstrates that reduced basal $\mathrm{I}_{\mathrm{sc}}$ in $o b / o b$ jejunum is attributed to a combination of decreases in: total epithelial protein expression of CFTR, contribution of basolateral $\mathrm{K}_{\mathrm{Ca}}$ channels and $\mathrm{Na}^{+} / \mathrm{K}^{+}$-ATPase. We conclude that consuming genisteindiet (600G) for 4-weeks reversed the deficit in basal $I_{s c}$ via the following sex-dependent mechanisms: in females; modification of the PDE3-dependent pathway and increased contribution of basolateral $\mathrm{K}_{\mathrm{Ca}}$ channels, whereas, in males; an increased contribution of $\mathrm{Na}^{+} / \mathrm{K}^{+}$-ATPase, and NKCC1 were noted. While this work contributes significantly towards the current limited understanding of small intestinal function in diabetes, and the complex mechanism(s) of action of genistein thereon, future studies will further examine potential additional cellular mechanisms involved.

\section{Abbreviations}

CFTR (cystic fibrosis transmembrane conductance regulatory protein); $\mathrm{NKCC1}\left(\mathrm{Na}^{+} /\right.$ $\mathrm{K}^{+} / 2 \mathrm{Cl}^{-}$cotransporter); $\mathrm{I}_{\mathrm{sc}}$ (transepithelial short circuit current); IBMX (8-methoxymethyl3-isobutyl-1-methylxanthine); EHNA (erthyro-9-(2-hydroxy-3-nonyl)adenine); ER/PI3K (estrogen receptor/phosphatidylinositol-3- kinase); PDE (phosphodiesterase enzyme); $\mathrm{H} \& \mathrm{E}$ (hematoxylin and eosin); DIDS (4,4'-diisothiocyanatostilbene-2,2'-disulfonic acid disodium salt hydrate).

\section{Acknowledgements}

The authors would like to thank most sincerely, Dr. Christian Lytle (University California, Riverside) for generous gift of NKCC1 antibody. Shawn Catmull and Robert Dolan were supported by the Midwestern University DO Summer Fellowship Program. Thanks to Ms Meghan Franco for technical assistance. Thanks to APS for supporting Amy Anderson (Basis High School, Phoenix) with a Frontiers in Physiology Research Award. This work was supported by Midwestern University Intramural funds (to L.A.), The Soy Health Research Program (to L.A.), and Diabetes Action and Research Education Foundation (to L.A.).

\section{Disclosure Statement}

None.

\section{References}

1 Drel VR, Mashtalir N, Llnytska O, Shin J, Li F, Lyzogubov VV, Obrosova IG: The leptin-deficient (ob/ob) mouse: a new animal model of peripheral neuropathy of type II diabetes. Diabetes 2006;55:3335-3343.

2 El-Salhy M: Gastrointestinal transit in an animal model of human diabetes type2: relationship to gut neuroendocrine peptide contents. Ups J Med Sci 2002;107:101-110.

3 Lin S, Yang Z, Liu H, Tang L, Cai Z: Beyond glucose: metabolic shifts in responses to the effects of the oral glucose tolerance test and the high-fructose diet in rats. Mol Biosyst 2011;7:1537-1548.

4 DeBosch BJ, Chi M, Moley KH: Glucose transporter 8 (GLUT8) regulates enterocyte fructose transport and global mammalian fructose utilization. Endocrinology 2012;153:4181-4191.

5 Anderson MP, Welsh MJ: Calcium and cAMP activate different chloride channels in the apical membrane of normal and cystic fibrosis epithelia. Proc Natl Acad Sci USA 1991;88:6003-6007.

6 Clarke LL, Grubb BR, Yankaskas JR, Cotton CU, McKenzie A, Boucher RC: Relationship of a non-cystic fibrosis transmembrane conductance regulator-mediated chloride conductance to organ-level disease in Cftr $\left({ }^{-/}\right)$mice. Proc Natl Acad Sci USA 1994;91:479-483. 


\section{Cellular Physiology Cell Physiol Biochem 2016;40:335-346

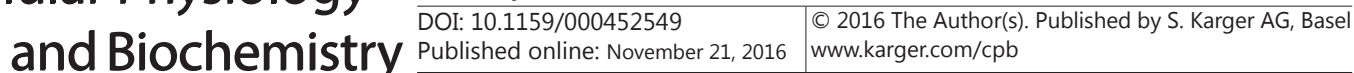 \\ Catmull et al.: Basal $\mathrm{Cl}^{-}$Secretion Increased by Genistein in $\mathrm{Ob} / \mathrm{Ob}$ Murine Jejunum}

$7 \quad$ Grubb BR: Ion transport across the normal and CF neonatal murine intestine. Am J Physiol 1999;277:G167-G174.

8 Leung L, Kang J, Rayyan E, Bhakta A, Barrett B, Larsen D, Jelinek R, Willey J, Cochran S, Broderick TB, AlNakkash L: Decreased basal chloride secretion and altered CFTR, villin and GLUT5 protein expression in jejunum from ob/ob mice. Diabetes Metab Syndr Obes 2014;7:321-330.

9 Murphy PA: Phytoestrogen content of processed soybean products. Food Tech 1982;36:60-64.

10 Al-Nakkash L, Hu S, Li M, Hwang T-C: A common mechanism for cystic fibrosis transmembrane conductance regulator protein activation by genistein and benzimidazolone analogs. J Pharmacol Exp Ther 2001;296:464-472.

11 Illek B, Fischer H, Santos GF, Widdicombe JH, Machen TE, Reenstra WW: cAMP-independent activation of CFTR Cl channels by the tyrosine kinase inhibitor genistein. Am J Physiol 1995;268:C886-C893.

12 Baker MJ, Hamilton KL: Genistein stimulates electrogenic $\mathrm{Cl}^{-}$secretion in the mouse jejunum. Am J Physiol 2004;287:C1636-C1645.

13 Al-Nakkash L, Clarke LL, Rottinghaus GE, Chen YJ, Cooper K, Rubin LJ: Dietary genistein stimulates anion secretion across female murine intestine. J Nutr 2006;136:2785-2790.

14 Chao P-C, Hamilton KL: Genistein stimulates electrogenic Cl- secretion via phosphodiesterase modulation in the mouse jejunum. Am J Physiol 2009;297:C688-698.

15 Xu X, Wang H, Murphy P, Cook L, Hendrich S: Daidzein is a more bioavailable soymilk isoflavone than is genistein in adult women. J Nutr 1994;124:825-832.

16 Tuo B, Wen G, Seidler U: Differential activation of the $\mathrm{HCO}_{3}{ }^{-}$conductance through the cystic fibrosis transmembrane conductance regulator anion channel by genistein and forskolin in murine duodenum. $\mathrm{Br} \mathrm{J}$ Pharm 2009;158:1313-1321.

17 Tuo B, Wen G, Song P, Xu J, Liu X, Seidler U, Dong H: Genistein stimulates duodenal $\mathrm{HCO}_{3}$ - secretion through PI3K pathway in mice. Eur J Pharmacol 2011;651:159-167.

18 Al-Nakkash L, Batia L, Bhakta M, Peterson A, Hale N, Skinner R, Sears S, Jensen J: Stimulation of murine intestinal secretion by daily genistein injections: gender-dependent differences. Cell Physiol Biochem 2011;28:239-250.

19 Al-Nakkash L: Genistein stimulates jejunal chloride secretion via sex-dependent, estrogen receptor or adenylate cyclase mechanisms. Cell Physiol Biochem 2012;30:137-150.

20 Clarke LL, Harline MC: CFTR is required for cAMP inhibition of intestinal $\mathrm{Na}^{+}$absorption in a cystic fibrosis mouse model. Am J Physiol 1996;270:G259-G267.

21 Clarke LL, Grubb BR, Gabriel SE, Smithies O, Coller BH, Boucher RC: Defective epithelial chloride transport in a gene-targeted mouse model of cystic fibrosis. Science 1992;257:1125-1128.

22 Sheldon RJ, Malarchik ME, Fox DA, Burks TF, Porreca F: Pharmacological characterization of neural mechanisms regulating mucosal ion transport in mouse jejunum. J Pharmacol Exp Ther 1989;249:572-582.

23 Devor DC, Singh AK, Gerlach AC, Frizzell RA, Bridges RJ: Inhibition of intestinal Cl- secretion by clotrimazole: direct effect on basolateral membrane K+ channels. Am J Physiol 1997;273:C531-C540.

24 Mall M, Gonska T, Thomas J, Hirtz S, Schreiber R, Kunzelmann K: Activation of ion secretion via proteinaseactivated receptor-2 in human colon. Am J Physiol 2002;282:G200-210.

25 Lexmond WS, Rufo PA, Fiebiger E, Lencer WI: Electrophysiological studies into the safety of the antidiarrheal drug clotrimazole during oral rehydration therapy. PLoS One Neglected Tropical Diseases 2015;9:e0004098.

26 Hamilton KL, Kiessling M: DCEBIO stimulates Cl- secretion in the mouse jejunum. Am J Physiol 2006;290:C152-C164.

27 Wu D, Hu Z: Rutaecarpine induces chloride secretion across rat isolated distal colon. J Pharmacol Exp Ther 2008;325:256-266.

28 Bajwa PJ, Lee JW, Straus DS, Lytle C: Activation of PPARg by rosiglitazone attenuates intestinal Cl- secretion. Am J Physiol 2009;297:G82-89.

29 Chen M, Du J, Jiang W, Zuo W, Wang F, Li M, Wu Z, Chan H, Zhou W: Functional expression of cystic fibrosis transmebrane conductance regulator in rat oviduct epithelium. Acta Biochim Biophys Sin 2008;40:864872.

30 Lamhonwah A-M, Bear CE, Huan LJ, Chiaw PK, Ackerly CA, Tein I: Cystic fibrosis transmembrane conductance regulator in human muscle dysfunction causes abnormal metabolic recovery in exercise. Ann Neurol 2010;67:802-808.

31 Favia M, Mancini MT, Bezzerri V, Guerra L, Laselva O, Abbattiscianni AC, Debellis L, Reshkin SJ, Gambari R, Cabrini G, Casavola V: Trimethylangelicin promotes the functional rescue of mutant F508del CFTR protein in cystic fibrosis airway cells. Am J Physiol 2014;307:L48-L61.

32 Zhang YR, Proenca M, Maffei M, Barone M, Leopold L, Firiedman JM: Positional cloning of the mouse obese gene and its human homologue. Nature 1994;372:425-432. 


\section{Cellular Physiology Cell Physiol Biochem 2016;40:335-346

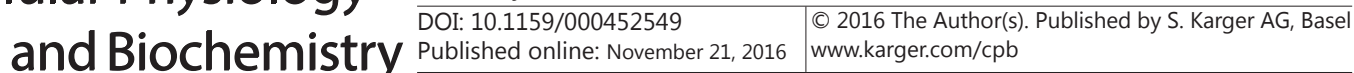 \\ Catmull et al.: Basal $\mathrm{Cl}^{-}$Secretion Increased by Genistein in $\mathrm{Ob} / \mathrm{Ob}$ Murine Jejunum}

33 Asakawa A, Inui A, Ueno N, Makino S, Uemoto M, Fujuno MA, Kasuga M: Ob/ob mice as a model of delayed gastric emptying. J Diabetes Complications 2003;17:27-28.

34 Roden M, Ludwig C, Nowotny P, Schneider B, Clodi M, Vierhapper H, Roden A, Waldhausl W: Relative hypoleptinemia in patients with type 1 and type 2 diabetes mellitus. Int J Obes 2000;24:976-981.

35 Aviello G, Matias I, Capasso R, Petrosino S, Borelli F, Orlando P, Romano B, Capasso F, Di Marzo V, Izzo AA: Inhibitory effect of the anorexic compound oleoylethanolamide on gastric emptying in control and overweight mice. J Mol Med 2008;86:413-422.

36 Bhetwal BP, An C, Baker SA, Lyon KL, Perrino BA: Impaired contractile responses and altered protein expression and phosphorylation of $\mathrm{Ca}^{2+}$ sensitization proteins in gastric antrum smooth muscle from ob/ ob mice. J Muscle Res Cell Motil 2013;34:137-149.

37 Verhulst PJ, Lintermans A, Janssen S, Loeckx D, Himmelreich U, Buyse J, Tack J, Depoortere I: GPR39, a receptor of the ghrelin receptor family, plays a role in the regulation of glucose homeostasis in a mouse model of early onset diet-induced obesity. J Neuroendocrinol 2011;23:490-500.

38 El-Salhy M, Spangeus A: gastric emptying in animal models of human diabetes: corelation to blood glucose level and gut neuroendocrine peptide content. Ups J Med Sci 2002;107:89-99.

39 O'Grady SM, Jiang X, Maniak PJ, Birmachu W, Scribner LR, Bulbulian B, Gullikson GW: Cyclic AMPdepdendent $\mathrm{Cl}$ secretion is regulated by multiple phosphodiesterase subtypes in human colonic epithelial cells. J Memb Biol 2002;185:137-144.

40 Steagall WK, Drumm ML: Stimulation of cystic fibrosis transmembrane conductance regulator-dependent short circuit currents across deltaF508 murine intestines. Gastroenterolgy 1999;116:1379-1388.

41 Nichols MR, Morimoto BH: Differential inhibition of multiple cAMP phosphodiesterase isoenzymes by isoflavones and tyrphostins. Mol Pharmacol 2000;57:738-745.

42 Ko W-C, Shih C-M, Lai Y-H, Chen J-H, Huang H-L: Inhibitory effects of flavonoids on phosphodiesterase isoenzymes from guinea pig and their structure-activity relationships. Biochem Pharmacol 2004;68:20872094.

43 Hamilton KL, Meads L, Butt AG: 1-EBIO stimulates $\mathrm{Cl}^{-}$secretion by activating a basolateral $\mathrm{K}^{+}$channel in the mouse jejunum. Pflugers Arch 1999;439:158-166.

44 Leung L, Bhakta A, Cotangco K, Al-Nakkash L: Genistein stimulates jejunum chloride secretion via an Aktmediated pathway in intact female mice. Cell Phys Biochem 2015;35:1317-1325.

45 Serhan MF, Kreydiyyeh SI: Insulin down-regulates the $\mathrm{Na}^{+} / \mathrm{K}^{+}$ATPase in enterocytes but increases intestinal glucose absorption. Gen Comp Endocrin 2010;167:228-233.

46 Ueda-Nishimura T, Niisato N, Miyazaki H, Naito Y, Yoshida N, Yoshikawa T, Nishino H, Marunaka Y: Synergic action of insulin and genistein on $\mathrm{Na}^{+} / \mathrm{K}^{+} / 2 \mathrm{Cl}^{-}$cotransporter in renal epithelium. Biochem Biophys Res Comm 2005;332:1042-1052.

47 Heaps C, Bowles D: Gender-specific $\mathrm{K}^{+}$-channel contribution to adenosine-induced relaxation in coronary arterioles. J Appl Physiol 2002;92:550-558.

48 Gaborit N, Varro A, Le Bouter S, Szuts V, Escande D, Nattel S, Demolombe S: Gender-related differences in ion channel and transporter subunit expression in non-diseased human hearts. J Mol Cell Cardiol 2010;49:639-646.

49 O'Mahony F, Alzamora R, Chung H-L, Thomas W, Harvey BJ: Genomic priming of the antisecretory response to estrogen in rat distal colon throughout the estrous cycle. Mol Endocrin 2009;23:1885-1899.

50 Uribe JM, McCole DF, Barrett KE: Interferon-g activates EGF receptor and increases TGF-alpha in T84 cells: implications for chloride secretion. Am J Physiol 2002;283:G923-931.

51 Martinez-Augustin O, Romero-Calvo I, Suarez MD, Zarzuelo A, Sanchez de Medina F: Moelcular bases of impaired water and ion movements in inflammatory bowel diseases. Inflamm Bowel Dis 2009;15:114-127.

52 Bell CJ, Gall DG, Wallace JL: Disruption of colonic electrolyte transport in experimental colitis. Am J Physiol 1995;268:G622-630.

53 Nakamura H, Yoshimura K, Bajocchi G, Trapnell BC, Pavirani A, Crystal RG: Tumor necrosis factor modulation of expression of the cystic fibrosis transmembrane conductance regulator gene. FEBS Letters 1992;314:366-370.

54 Besancon F, Przewlocki G, Baro I, Hongre A-S, Escande D, Edelman A: Interferon-gamma down regulates CFTR gene expression in epithelial cells. Am J Physiol 1994;267:C1398-1404.

55 Stenman LK, Holma R, Gylling H, Korpela R: Genetically obese mice do not show increased gut permeability or faecal bile acid hydrophobicity. Br J Nutr 2013;110:1157-1164.

56 Brun P, Castagliuolo I, Di Leo V, Buda A, Pinzani M, Palu G, Martines D: Increased intestinal permeability in obese mice: new evidence in the pathogenesis of nonalcoholic steatohepatitis. Am J Physiol 2007;292:G518-G525. 